\title{
Women Entrepreneurs and Business Angel: A Difficult Relationship
}

\author{
Ferdinando Giglio ${ }^{1}$ \\ ${ }^{1}$ Department of Economics, University of Campania "Luigi Vanvitelli”, Capua, Italy \\ Correspondence: Ferdinando Giglio, PhD at University of Campania "Luigi Vanvitelli", Corso Gran Priorato di \\ Malta, 1, Capua, 81043, Italy. E-mail: ferdinando.giglio@unicampania.it
}

Received: August 3, 2021

Accepted: September 23, $2021 \quad$ Online Published: September 25, 2021

doi:10.5539/ijef.v13n11p21

URL: https://doi.org/10.5539/ijef.v13n11p21

\begin{abstract}
This article aims to analyze the phenomenon of the business angel, considered one of the main ways of obtaining external financing by women entrepreneurs.

Through a search conducted on the Scopus database, 26 articles have been selected that deal with the problem of finding external sources required by women entrepreneurs. It has been shown that women entrepreneurs are discriminated against by business angels for various reasons including the lack of work experience acquired, the level of education and the lack of social networks useful for interacting with them. The business angel phenomenon has been analyzed in China, Japan, and Sweden, therefore, research could be conducted in Italy, given the scarcity. Furthermore, only the business angel was analyzed as a source of external financing so other ways to receive resources from the external environment could be discussed. This is an article that deals with the problem on how women entrepreneurs find themselves having to face when they decide to start their own business.
\end{abstract}

Keywords: access to credit, business angel, women entrepreneurs

\section{Introduction}

Entrepreneurship is still a primarily male-run business in the 21 st century. Despite rising participation rates in new business development among women, they remain underrepresented (Reynolds, Bygrave, Autio, Cox, \& Hay, 2003). Not only do female entrepreneurs start entrepreneurship less than men, but the few who take this step appear to have less growth than their male counterparts (Cliff, 1998). Brush, Carter, Gatewood, Greene, and Hart (2004) believe that a funding gap is holding back the expansion of women-run businesses. Barriers to access to seed capital represent a major challenge for female businesses (Alsos et al., 2006; Brush et al., 2004a, 2004b; 2006; Harrison \& Mason, 2007; Robb et al., 2013; Azam et al., 2009), since external financing is a significant element for the survival and growth of firms in the early stage (Amit et al., 1990; Berger \& Udell, 1998).

A significant source of external funding for early stage initiatives is angelic investment. Angel funding (Wong et al., 2009) is an important source for entrepreneurial ventures because angels are more likely to invest in risky phases (Maxwell et al., 2011; Preston, 2004).

The article is divided into the following parts: the first part provides a background on female entrepreneurship and the success experienced by female entrepreneurs; in the second part, on the other hand, some obstacles encountered by female entrepreneurs are analyzed, including the problem of access to credit and financing by business angels; the third part illustrates the definitions and characteristics of business angels; the fourth part analyzes the phenomenon of business angels in the various states; in the fifth part, moreover, the relationship that is established between the woman entrepreneur and the business angel is discussed and in the sixth and last part the limits and conclusions are presented.

\section{Female Entrepreneurship: Theoretical Background}

The literature on traditional entrepreneurship dating back to the 1930s has mainly focused on the figure of the male entrepreneur. The late 1970s saw the emergence of a subdomain of female entrepreneurship (Jennings \& Brush, 2013). In 1976, Schwartz published the first academic article on female entrepreneurship in the Journal of Contemporary Business and the first political report titled "The bottom line: Unequal enterprise in America" was published in 1979 in Washington.

De Hisrich and O'Brien (1981) held the first academic conference on female entrepreneurship at the Bobson College Conference on Entrepreneurship in 1981. The first academic book was published in 1985 (Goffee \& Scase, 
1985).

Initial research on entrepreneurship argued that male and female entrepreneurs were generally the same and that a separate survey was not necessary (Bruni et al., 2004). As a result, the subdomain of female entrepreneurship did not develop as a major area until the late 1990s and early 2000s (Jennings \& Brush, 2013) with two dedicated conferences. In 1998, the first of these conferences was held, managed by the Organization for Economic Co-operation and Development (OECD) with a focus on entrepreneurship policies in SMEs. In 2003, on the other hand, an academic conference called Diana International was held, a multi-university research program to identify the factors that support and allow the exponential growth of businesses run by women. The group combines in-depth research on a new business strategy, international entrepreneurship (Candida Brush), founding strategies of new businesses, minority initiatives (Nancy Carter), entrepreneurial knowledge, motivations for start-ups (Elizabeth Gatewood), resource entrepreneurs, minority entrepreneurs (Patricia Greene) and high-growth entrepreneurship (Myra Hart).

The project is based on two objectives, to provide a platform from which to develop, guide and share a global research agenda; and create an international community of scholars dedicated to answering questions about growth-oriented entrepreneurs and businesses.

There are some studies that suggest that women have some advantages in specific functions in management, mainly people-related managerial functions, which would lead to higher performance. For example, women would focus more on developing their teams than men; they would show a higher level of empowerment in their activities and would also encourage the success and perseverance of their employees (Bruni et al., 2004; Gundry et al., 2002). The benefits of women would come from spending more time networking, being more engaged in conducting market research and achieving better results in strategic planning, driving change (Greve \& Salaff, 2003; Lerner et al., 1997; Lerner \& Almar, 2002; Morris et al., 2006; Walker \& Webster, 2006) and innovation (Goldsmith et al., 1987; 1995; Hisrich \& Brush, 1984; Sexton \& Bowrnan-Upton, 1990).

Other researchers found no gender differences in success indicators, such as longevity, turnover or growth (Fagenson, 1993; Kalleberg \& Leicht, 1991; Menzies et al., 2004; Sonfield et al., 2001; Verheul et al., 2002; Verheul \& Thurik, 2001; Watson, 2002). Other studies, on the other hand, give empirical evidence that the performance between male and female entrepreneurs are not significantly different, suggesting that their managerial performances and attitudes are identical in many respects (Chaganti \& Parasuraman, 1996; Menzies et al., 2004; Orser \& Equitation, 2004; Watson, 2002).

\section{Women Entrepreneur's Problems}

Despite their success, women entrepreneurs continue to find themselves in a position below men due to various problems: first of all, the problem of access to credit (Nichter \& Goldmark, 2009) and the different ways of receiving resources from external environment. Evidence reiterates that female entrepreneurs face more challenges than men. For example, women start a business with fewer resources than their male counterparts (Carter \& Allen, 1997; Boden \& Nucci, 2000); they have slower and less reliable supplier order delivery (Weiler \& Bernasek, 2001) and more limited access to corporate customers (Bates, 2002). Women also struggle to get funding for new ventures in the form of debt (Buttner \& Rosen, 1988; Fay \& Williams, 1993; Riding \& Swift, 1990; Coleman, 2000) and venture capital (Seegull, 1998; Greene et al., 2001; Brush et al., 2002).

Indeed, Brush (1992; 1997) and Carter et al. (2003) argue that the acquisition of seed capital is a major concern of WOBs (companies owned or led by women). The difficulty of WOBs in securing start-up financing is worrying given the importance that early stage capital decisions have on the performance, growth and survival of new ventures (Cassar, 2004). Early-stage equity financing plays an important role in the successful launch and development of business ventures (Wetzel, 1986; Ou, 1987; Gaston \& Bell, 1988; Mason \& Harrison, 1992). To date, research on WOB access to capital at an early stage has focused on the venture capital market. Although the latter is a key source of funding for start-ups, it is not the most widespread source of private equity funding for new ventures (Freear \& Wetzel, 1992; Brophy, 1997; Mason \& Harrison, 1999; Brush et al., 2002).

Rather, the research states that angel investors are the primary source of start-ups and seed capital for business ventures in the United States and Europe (Berger \& Udell, 1998; Harrison \& Mason, 2000; Sohl et al., 2000; GEM, 2001; Sohl, 2003; Bygrave \& Reynolds, 2004). Freear and Wetzel (1992) and Mason and Harrison (2000) argue that the acquisition of angel capital could be a significant first step in receiving institutional venture capital.

\section{Business Angel: Definitions and Characteristics}

Business Angels are high net worth individuals who invest a portion of their wealth in high-risk, high-return business projects (Freear et al., 1994; Avdeitchikova et al., 2008). The capital can be provided at the beginning or 
during the activity on an ongoing basis.

There are two types of angel investors, affiliated and unaffiliated. An affiliated angel is one who has a relationship with the entrepreneur. Affiliate angels include business associates such as suppliers, customers, employees, or competitors. An unaffiliated investor angel, on the other hand, is an angel who has no connection with either the entrepreneur or the company. They are lawyers and accountants, consultants, managers and any other person with high net worth that the entrepreneur does not know personally. Also important are angel groups or business angel networks.

Angel groups are individual angels who meet to evaluate and invest in business projects, meet to evaluate business proposals, work together to conduct due diligence, evaluate plans, and decide whether to invest in businesses.

Business angel research is usually classified into three subject areas: business angel characteristics, market, and investment process.

The first thematic area concerns the characteristics of business angels. It exposes the profile of business angels in terms of business background, experience and training, investment motivation and investment criteria, behavior and activities. Within this thematic area, four lines of research have been identified.

"Profiles and typologies" is the most detailed research line. A first set of tests provides a description of business angel profiles in terms of portfolio size, investment motivations and preferences, syndication strategies (Wetzel, 1983; Aram, 1989; Moen et al., 2008; Lahti, 2011a), psychological traits (Duxbury et al., 1996), business background and experience, investment criteria and outcomes (Landstrom, 1992; Paul et al., 2003) and factors that differentiate professional business angels from non-investors or capital providers family and friends (Maula et al., 2003; Wong \& Ho, 2007; Li et al., 2014a; 2014b). Business angels are represented as male subjects, with high net worth, with considerable entrepreneurial experience and who negotiate for investments especially in the initial phase (Wetzel, 1983; Aram, 1989; Maula et al., 2005; Wong \& Ho, 2007; Riding, 2008). They are generally investors with a great deal of patience, driven by non-financial motivations and eager to be involved in the post-investment management of their companies (Wetzel, 1983; Duxbury et al., 1996).

In the second line of research "International differences in profiles", the characteristics and behaviors of business angels between different countries and institutional contexts are compared. The comparison is made between the more developed US financial market and the European one (Harrison \& Mason, 1992; Landstrom, 1993; Wilson, 1995; Brettel, 2003), between different European countries (Bygrave et al., 2003; Stedler \& Peters, 2003; Ding et al., 2015) and also between emerging and consolidated economies (Li et al., 2014a; 2014b; Scheala et al., 2015).

Evidence shows that compared to the United States, European business angels invest smaller amounts, are less patient and less risk averse (Wilson, 1995; Brettel, 2003).

As for the differences between emerging and developed economies, it was found that business angels in China tend to make more localized investments than the United States and Europe. They are also less patient and less involved in their companies in the post-investment phase ( $\mathrm{Li}$ et al., 2014a; 2014b). A significant difference has emerged between business angel research in developed and emerging economies. Despite the "institutional gaps", business angels in emerging countries actively support the financing and development of business projects. Business angels in developed countries, on the other hand, co-invest to reduce financial risk (Scheela et al., 2015).

The third line of research, called “Gender”, focuses on women's access to angelic capital (O'Gorman \& Terjesen, 2006; Becker-Blease \& Sohl, 2007), women's characteristics, business angel investment preferences (Harrison \& Mason, 2007; Sohl \& Hill, 2007) and on the effects of gender diversity on the investment behavior of the group of angels (Becker-Blease \& Sohl, 2011). It has been found that women seek angelic funding at lower rates than their counterparts (Becker-Blease \& Sohl, 2007) and tend to invest less when they are in the minority as in angelic groups (Becker-Blease \& Sohl, 2011).

The latest research line "Networks and Groups" focuses on the new roles played by business angels emerging from the development of networks and groups. The emerging figures are the "guardians" (Paul \& Whittom, 2010) and the "neyus angels" (Porter \& Spriggs, 2013).

The second thematic area is the market which was one of the first themes addressed in the research (Wetzel, 1987). Within this thematic area three lines of research have been identified.

The first line of research is "Supply and Demand for Angelic Capital". Several pieces of evidence give estimates of the total business angel market in both the United States (Wetzel, 1987; Gaston, 1989) and the United Kingdom (Mason \& Harrison, 2000, 2008), while other papers have focused on understanding micro and macro determinants of the supply and demand for angel financing. The results reveal that the demand for informal 
investments generates its own supply of finance, due to both micro and macro factors (Burke et al., 2010; De Clercq et al., 2012; 2014). This literature stream analyzes the impact of business cycles (Sohl \& Rosenbers, 2003; Mansson \& Landstrom, 2006) and changes in national tax systems and government regulations (Mansson \& Landstrom, 2006; Szub et al., 2007a, 2007b; Tingchi \& Chang, 2007).

The second line of research is "Effectiveness of angel funding on regional growth," which includes studies investigating the role of business angels in bridging regional financial gaps and stimulating regional economic growth. Several studies identify business angels (Harrison \& Mason, 1991) and business angel networks - BAN(Mason \& Harrison, 1995; Aernouott, 2004) as the key to curbing the new equity gap left by venture capital in the initial and to encourage entrepreneurship at the regional level. It was found that in Sweden investment by business angels continues to be concentrated in metropolitan and university areas (Avdeitchikova, 2009), while in Scotland there is a significant structural gap for capital development and expansion that is not bridged by BAN (Harrison et al., 2010a; Gregson et al., 2013). This is due to the withdrawal of venture capital from new investments and from business angels that have increased the size of the deal.

The latest line of research "Policies to promote the informal venture capital market" evaluates the effectiveness of government policies to aid the investment activities of business angels. It is a flow that has remained underestimated. Several pieces of evidence in this line of research include the evaluation of existing government policies (Mason \& Harrison, 1997a; 1997b; Lerner, 1998; Mason \& Harrison, 2004b; Aernoudt et al., 2007; Knyphausen-Aufse \& Westphal, 2008; Collewaert et al., 2010; Christensen, 2011; Romani et al., 2013; Boldock \& Mason, 2015). Some suggestions are made to encourage the informal venture capital market, including policy measures to facilitate the connection between business angels and entrepreneurs, such as the introduction of business services and financial meeting at the regional level (Mason \& Harrison, 1992; 1993; 1995), to stimulate syndication, promote co-investment schemes and BAN activities, improve investor readiness, create angel business schools (San Jose et al., 2005), and establish investment companies partnership for new initiatives and to integrate different funding resources (Aernoudt, 2005).

The last thematic area "Investment process" includes four lines of research, selection, evaluation, and financing, post-investment, impact on the performance of subsidiaries and overview of the entire investment process.

The first line of research "Selection, evaluation and financing" is the one explored in the investment process of the thematic area on business angels. This flow of literature describes the determinants of business angel decision-making at both individual and group levels (Landstrom, 1998; Mason \& Harrison, 1996b; Saetre, 2003; Sorheim, 2003; Gimmon, 2008; Harrsion et al., 2010b; Brush et al., 2012; Mitteness et al., 2012b; Argerich et al., 2013; Ding et al., 2014; Rostamzadeh et al., 2014; 2015), with a detailed focus on the criteria used for not accepting proposals commercial (Maxwell et al., 2011; Carpentier \& Suret, 2015a), with respect to the decision-making criteria adopted by other types of investors, such as venture capital and bankers (Haar et al., 1988; Fiet, 1995a; 1995b; Guild \& Bachler, 1996; Mason \& Stark, 2004; Gimmon, 2008; Ibrahim, 2008; Fairchield, 2011; Conti et al., 2013; Hsu et al., 2014; 2015; Hellmen \& Thiele, 2015).

Finally, few studies investigate the negotiation phase, focusing on how business angel contracts affect their involvement in invested firms (Kelly \& Hay, 2003), compared to venture capital contractual arrangements (Ibrahim, 2008) and the challenges faced by entrepreneurs in the terminal phase of agreements with business angels (Amatucci \& Swartz, 2011; Dauglas et al., 2014).

The second line of research "Post-investment phase" includes academic works describing the value-added roles of business angels (Mason \& Harrison, 1996a; Sorheim, 2005; Macht \& Robinson, 2009; Macht, 2011; Fili, 2014; Bjorgum \& Sorheim, 2015).

In the third line of research "Impact on the performance of investee companies", several evidence shows that investment returns of business angels have a large variance and are negatively skewed with many losses and few extraordinarily high returns (Mason \& Harrison, 2002b). Business angels usually have a fairly short holding period (4 years) and commercial selling is the most frequent exit strategy that is preferred even by groups of angels to exit the IPO (Roach, 2010; Capizzi, 2015; Carpentier \& Suret, 2015b), although angel-backed companies perform best through IPOs (Mason \& Harrison, 2002b). Another stream of literature investigates the impact of trust and business angel network connections on the performance of investee companies (Bamners \& Colleweart, 2012; Werth \& Boeert, 2013). Business angels' perceptions of trust have been shown to lead to a higher performance of perceived risk capital up to a certain threshold, beyond which the positive effect is supplanted (Bamners \& Colleweart, 2012). In addition, initiatives supported by better connected business angels are more likely to receive later venture capital funding and successfully exit through commercial sales or IPOs (Werth \& Boeert, 2013).

In the latest research line "Overview of the entire investment process" various studies investigate the role played 
by different institutional contexts on the investment process of business angels in emerging economies, such as Thailand, China, Philippines (Scheela \& Isidro, 2008; 2009; Xiao \& Ritchie, 2011; Scheela \& Iittrapanun, 2012). Amatucci and Sohl (2004), Paul et al. (2007) and Festel and De Cleyn (2013b) give a description of the different phases of the investment process of business angels, focusing on the comparison with the venture capital process, on the role of gender in research, negotiation and post-investment and on practices specific investment strategies of the founding angels, while Elitzur and Gavious (2003) give life to a theoretical model that describes the interactions between an entrepreneur, a business angel and a venture capital during the investment process, underlining that, due to moral hazard, the entrepreneur and the venture capitalist are incentivized to exceed the initial investment made by the business angels for free. Business angels are involved in the selection phase and first contact with the entrepreneur, while venture capitalists take the initiative in the structuring phase of the operation (Bonnet \& Wirtz, 2012).

\section{The Phenomenon of Business Angel in Different Countries}

The business angel phenomenon has been implemented in several countries. For example, a sample of twenty companies that received loans under a Japan Development Bank (JDB) special program to finance high-tech venture capital businesses were examined to determine the role of business angels in their financing. The JDB is one of the most influential government financial institutions in Japan. It grants loans to businesses to implement various government goals such as technological, regional, urban development and energy saving. The JDB recently launched a new program known as "Business Support Loans" which targets high-tech companies in need of R\&D funding for manufacturing facilities.

In China, however, the $3 \mathrm{~A}$ model has been developed. The three dimensions are skill, attitude and action which are defined as follows:

the skill dimension which refers to the possession of the liquidity required for the angel investment;

the attitude dimension that explores the willingness of individuals to invest in start-ups;

the size of the action that is the result of the joint operation of ability and attitude (which refers to the fact that individuals have already made angelic investments).

Regarding the skill dimension, which refers to having sufficient liquidity for investment, not all business angels in China show high personal wealth: over two-thirds have an annual family income of less than one million. RMB $(\$ 154,828)$. Regarding family net worth, $39 \%$ have a net worth of less than RMB two million $(\$ 309,655)$, while $20 \%$ say their family's net worth exceeds RMB ten million $(\$ 1,548,275)$. Compared to business angels in other countries, angels in China have a relatively lower annual income and household net worth (Manion, 1994).

As for the attitude dimension, which investigates the willingness of individuals to invest in start-ups, it has been found that business angels in China are inexperienced. So far more than half (59) have invested in a single start-up, while investors who have made two or more investments represent $41 \%$ (serial investors).

Finally, as regards the size of the action, which is the result of the joint operation of skills and attitudes, it was found that the family business is the main business model for business angels and is responsible for a large part of the flow of agreements, which may be the result of the lack of necessary institutions in emerging economies (Scheela \& Jittrapanun, 2012).

The business angel phenomenon is also present in Sweden. Mason and Harrison (1999; 2000b; 2002a) studied business angels in relation to their perception of changes in taxation levels, changes in the economic environment, such as altered interest rates, inflation and economic growth. and, finally, the perception of the price of fluctuations in the real estate and stock markets, as well as the importance of the presence of public markets for small businesses.

In the first area, according to Mason and Harrison (2000b), front-end tax relief systems are an incentive that positively affects business angels' willingness to invest. Sweden, however, has had a short and temporary history of this type of tax regime and it is therefore impossible to assess its impact on investment. Instead, it is more pertinent to talk about other changes in this sector after the crisis of the early 1990s. First, the corporate tax rate was reduced to $28 \%$ in 1991 after doubling in the 1980s.

Second, a fixed tax of $30 \%$ on capital gains was introduced and the wealth tax on unlisted shares was abolished. This means that equity investments today are more favorable than they were in the 1980s (Hernekson, 2001), suggesting that angel investments are likely to have increased between 1992 and 2004.

In the second area, Mason and Harrison (1999; 2000b; 2002a) indicate that economic conditions, like changes in interest rates, inflation and GDP, have a moderate effect on business angels' willingness to invest. This conclusion 
is based on the lesser impact of negative economic development on the willingness to invest.

However, lower interest rates, lower inflation and rising GDP have a relatively large positive effect on the willingness to invest. While nearly all business angels believe that an expanding economy has a positive effect on their willingness to invest, a minority of business angels are of the opinion that a stable or declining economy has no impact (Mason \& Harrison, 2000b). Furthermore, some argue that a stable or declining economy can have a positive effect on the level of investment. This implies that some business angels may consider the risk of overvaluation of unlisted companies in times of rapid economic growth. The effects of interest rates and inflation are considered to be less than the effect of changes in GDP. In the Mason and Harrison study (2000b), most business angels believed that falling or stable interest rates had a positive influence on their willingness to invest, and about half believed that low inflation would have some positive effect on their willingness to invest. their willingness to invest.

Sweden has been found to have had more stable economic conditions since the early 1990s. This is related to the exemption from capital and foreign exchange markets in combination with a strict central government balance sheet from the early 1990s and an independent central bank (Henrekson, 2001).

The result was a drastic reduction in inflation and a fall in interest rates. Finally, the positive effects of the very stable economic climate are believed to further raise expectations for greater investments by business angels.

The effect of stock market trends is the latest area investigated by Mason and Harrison (2000b; 2002a) and can influence the willingness to invest in different ways. The wealth of business angels is determined by stock market trends, although stock market returns also drive the higher return of unlisted companies and, if that seems unlikely, investments will be made in listed companies. Interviewees in the Mason and Harrison study (2000b) show that business angels as a group appear to be indifferent to changes in the stock market with regards to their willingness to invest in unlisted SMEs, and stock market developments are unlikely to have influenced amounts invested. However, the Stockholm Stock Exchange had the fastest rise of all stock exchanges in the industrialized world during the 1980s and 1990s (The Economist, 1999), and a strong market can indirectly increase the investment opportunities of business angels. cause of capital growth.

However, one aspect that may have had a dampening effect on informal investments made in the years leading up to the 2004 study is the low level of IPOs after the dotcom crash. It is important for business angels to have an open stock market for IPOs, and the Mason and Harrison study (2000b) shows that the lack of opportunities to spawn new companies on the public stock market negatively affects the willingness of business angels to invest in securities. not listed. However, the backlash of the dot-com crash came after an increase in IPOs on the Stockholm Stock Exchange and the number of alternative equity markets during the 1990s.

This could imply that business angels viewed the "closed" IPO market as a temporary problem. Regardless of whether the closed IPO market is seen as a temporary problem or not, it goes without saying that the lower chances of going public have hurt both the formal and informal venture capital markets. However, the fact that prices rose rapidly on the Stockholm Stock Exchange (The Economist, 1999) along with lower taxes (Henrekson, 2001; Davidsson \& Henrekson, 2002) and rapid wage increases (Davis \& Henrekson, 2000) indicates an increase of wealth among business angels. The fact that the 2004 study was conducted shortly after the dot-com crash in a climate of falling stock prices and a near moribund IPO market indicates a temporary decline in informal venture capital investments. This reveals that stock market developments led business angels to invest at the same level or below the same level in unlisted companies in 2004 as in 1992.

\section{Women Entrepreneurs and Business Angels}

Let us now address the potential differences between women and men on the issue of accessing angelic finance. Businesswomen have been found to obtain angel loans at a lower rate than their counterparts. Two feminist traditions have been proposed in the exploration of business women: liberal and social models (Fischer et al., 1993; Liou \& Aldrich, 1995; Brush, 1997; Carter \& Allen, 1997; Cliff, 1998).

The liberal model, called the situational perspective, argues that men and women are equal with identical mental abilities and the same rationality. Therefore, the observed differences are based on inequality of access to essential opportunities such as education, job opportunities and social networks. Social feminism, referred to as a dispositional perspective, states that women (WOB) and men (MOB) are different but with equally valid perceptions, motivations and belief structures. Although both traditions are appropriate structures by which to verify women's access to angel capital, several studies allow for discussion of the liberal model. There are two fundamental aspects through which female entrepreneurs receive angelic funding. The first is the rate at which women seek angelic funding. Liberal feminist theory predicts that barriers to education, social networks and 
related work experiences prevent women from seeking funding (Borden \& Nucci, 2000; Greene et al., 2001).

Although few differences have been found between the educational level of men and women entrepreneurs (Birley et al., 1987; Fischer et al., 1993), the areas of education differ (Powell, 1993; Brush, 1997; AAUW, 2004; Menzies et al., 2004). The National Science Foundation's Statistics Division of Science Resources notes that men earned most of their science and engineering degrees in the 1990s. Similarly, women make up only $30 \%$ to $40 \%$ of MBA students (Catalyst, 2000; AACSB, 1997). These proportions are reflected in the professional workforce. The Bureau of Labor Statistics reports that of the professionals working in 2001, women made up only $12.9 \%$ of engineers, $20.3 \%$ of physicians, $30.8 \%$ of mathematicians and computer scientists, $35.2 \%$ of natural scientists and $45.9 \%$ of administrative and professional managers.

Therefore, the supply of WOBs in the high-growth industries that angelic capitalists tend to finance will be lower than that of male entrepreneurs. The second aspect with which WOBs receive funding from angels is the actual rate of return of the proposals. The rate of return is the probability that a given proposal will receive funding. There are several explanations as to why WOBs would be funded at a lower rate than MOBs. Women can be discriminated against by capitalist angels because they believe they are less capable or less confident than their male counterparts. Buttner and Rosen (1988) and Fay and Williams (1993) reiterate that bankers perceive that men have more characteristics associated with successful entrepreneurship than female entrepreneurs.

Furthermore, they are discriminated against because they generally have less relevant work experience, are more likely to have non-corporate responsibilities or have no social networks to interact with business angels (Boden \& Nucci, 2000; Greene et al., 2001). Given their educational and professional backgrounds, women are also more likely to start a business in an industry that generally does not receive risk finance due to growth prospects or familiarity with the business angel (Brush, 1997).

Business angels also refuse to help WOBs for several reasons. Bates (2002) notes that WOBs have limited access to corporate clients compared to MOBs that control size, age and industry. Similarly, Weiler and Bernarek (2001) believe that delivery times and orders from suppliers to WOBs are slower and less reliable than MOBs. Another theory, which addresses the problem of discrimination against female entrepreneurs by business angels, is the theory of social identity. This theory has its roots in social psychology (Hagge et al., 1995) and is based on the principles of group identification. Helps explain group processes and intergroup relationships (Tajfel \& Turner, 1979). In social identity theory, the concept of self in a person derives from the groups of values to which that person belongs or aspires to belong. The person sees things from the group's perspective, regardless of whether she has direct interaction with the group (Ashforth \& Moel, 1989) and individuals have multiple identities associated with their respective affiliated groups (Meister et al., 2014). In social identity theory, there are three social processes that give rise to a mentality within the group versus one outside it: categorization, identification and social confrontation.

Social categorization is a process in which people are classified in order to be better understood and identified. Social identification is the process by which individuals adopt the norms and behaviors of that particular group (Turner, 1982). Social identity is the process of social confrontation. After individuals have been characterized and identified with groups, they are compared with those groups and with others (Tajfel, 1982; Turner, 1982).

Among them, social categorization is the most important component of social identity theory. Categorization is the cognitive basis of group behavior and the categorization of in-group versus out-group takes away the unique individuality and replaces it with stereotyped prototypes (Hagg \& Terry, 2000). A feature of prototypes is that they maximize similarities within the group and differences outside the group (Hagg \& Terry, 2000). In the context of angel investing, it has been found that in decision making, angel investors can be influenced by shared beliefs about the characteristics attributed to men and women and the appropriateness of behavior in the context of investments (Fiske, 2000). Entrepreneurship is traditionally seen as a male reserve, the image of the entrepreneur is more often male, and men tend to own investor-preferred assets that are more profitable and rapidly growing (Brush et al., 2006; Ahl, 2006; Bruni et al., 2004; Bird \& Brush, 2002). Research on stereotypical male behaviors of entrepreneurs suggests that the perceived incongruity between entrepreneurship and femininity creates obstacles for female entrepreneurs (Gupta et al., 2009; Eddleston et al., 2016; Justo et al., 2018; Wheadon \& Duval-Caultil, 2007). A recent study, which examines how government venture capitalists construct gender stereotypes when assessing the potential of male and female entrepreneurs, found that the potential of women can be undermined while that of men is supported because they prevail in context (Malmstrom et al., 2017).

\section{Conclusions and Limitations}

The first part of this work discussed the success experienced by women entrepreneurs. In 1976 Schwartz published the first academic article on female entrepreneurship in the Journal of Contemporary Business; various 
conferences have been held on this theme. Among these is the 1998 conference held by the OECD mainly focused on the policies of women entrepreneurs in SMEs. Also important was the Diana project, defined as a multi-university research program, to identify the factors that support and enable high growth of women-led companies. Subsequently, in the second part, some obstacles encountered by female entrepreneurs were identified. The problem, still present today, is the access to credit and financing that entrepreneurs receive from business angels in the initial stages of their business. Business angels are individuals with high net worth who invest a portion of the latter in high-risk, high-return business ventures (Freear et al., 1994; Avdeitchikova et al., 2008).

It has been found that women are discriminated against by capitalist angels because they are deemed less capable or less confident than men. Buttner and Rosen (1988) and Fay and Williams (1993) report that bankers perceive that men have more characteristics associated with successful entrepreneurship than female entrepreneurs. Furthermore, it has been shown that women are discriminated against because they usually have less relevant work experience; they are more likely to have non-corporate responsibilities or have no social networks to interact with business angels (Boden \& Nucci, 2000; Greene et al., 2001). There are several limitations to this work. First of all, the phenomenon of "business angels" has only been analyzed in a few states including China, Sweden and Japan. Research could therefore be carried out in Italy on this phenomenon, given the scarcity. Furthermore, another limitation is that of having analyzed only the phenomenon of business angels as a source of external financing. Other forms of external financing could be included in the work. All of these problems can be addressed in future research.

\section{References}

Agnete, A. G., Isaksen, E. J., \& Ljunggren, E. (2006). New Venture Financing and Subsequent Business Growth in Men- and Women-Led Businesses. Entrepreneurship: Theory and Practice, 30(5), 667-686. https://doi.org/10.1111/j.1540-6520.2006.00141.x

Aldas-Manzano, J., Martinez-Fuentes, C., \& Pardo-del-Val, M. (2012). Women Entrepreneurship and Performance. Chapter. Women's Entrepreneurship and Economics, International Studies in Entrepreneurship, 89-108.

Amatucci, F. M., \& Jeffrey, E. (2004). Women entrepreneurs securing business angel financing: Tales from the field. Venture Capital, 6(2/3), 181-196. https://doi.org/10.1080/1369106042000223579

Argerich, J. C. (2017). Definition, sampling, and results in business angel's research: Towards a consensus. Management Decision, 55(2), 310-330. https://doi.org/10.1108/MD-07-2016-0487

Asma, A., Al Khayyal, O., Alshurideh, M., Al Kurdi, B., Said, S., \& Salloum, A. (2020). Women Empowerment in UAE: A Systematic Review. Conference paper: Proceedings of the International Conference on Advanced Intelligent Systems and Informatics 2020.

Becker-Blesse, J. R., \& Sohl, J. E. (2007). Do women-owned businesses have equal access to angel capital? Journal of Business Venturing, 22(4), 503-521. https://doi.org/10.1016/j.jbusvent.2006.06.003

Boulton, T., Shohfi, T., \& Zhu, P. (2016). Angels or Sharks? The Role of Personal Characteristics in Angel Investment Decisions. SSRN Electronic Journal, 57(4), 1280-1303. https://doi.org/10.1111/jsbm.12409

Brett, A., \& Dumay, J. (2017). Business angels: a research review and new agenda. Venture Capital, 19, 1-34. https://doi.org/10.1080/13691066.2017.1290889

Brettel, M. (2003). Business angels in Germany: A research note. Venture Capital, 5(3), 251-268. https://doi.org/10.1080/1369106032000122095

Candida, G., Brush, M., Nancy, M., Carter, E., Patricia, G., Greene, E., Myra, M., Hart, M., \& Gatewood, E. (2002). The role of social capital and gender in linking financial suppliers and entrepreneurial firms: A framework for future research. Venture Capital, 4(4), 305-323.

Dibrova, A. (2015). Business angel investments: Risks and opportunities. Procedia - Social and Behavioral Sciences, 207, 280-289. https://doi.org/10.1016/j.sbspro.2015.10.097

Edelman, L. F., Donnelly, R., Manolova, T., \& Brush, C. (2018). Gender stereotypes in the angel investment process. International Journal of Gender and Entrepreneurship, 10(2), 134-157. https://doi.org/10.1108/IJGE-12-2017-0078

Edelman, L. F., Manolova, T. S., \& Brush, C. (2017). Angel Investing: A Literature Review. Foundations and Trends in Entrepreneurship, 13(4-5), 265-439. http://dx.doi.org/10.1561/0300000051

Gatewood, E., Brush, C., Carter, M., Greene, P., \& Hart, M. (2009). Diana: a symbol of women entrepreneurs' hunt 
for knowledge, money, and the rewards of entrepreneurship. Small Bus. Econ., 32(2), 129-144.

Harrison, R., \& Mason, C. (2007). Does Gender Matter? Women Business Angels and the Supply of Entrepreneurial Finance. Entrepreneurship: Theory and Practice, 31(3), 445-472. https://doi.org/10.1111/j.1540-6520.2007.00182.x

Holmquist, C., \& Carter, S. (2009). The Diana Project: pioneering women studying pioneering. Small Business Economics, 32(2), 121-128.

Khalid, R., Muneeb, M. A., \& Serfraz, A. (2020). Role of women entrepreneurs in economic activities: analyzing the factors affecting women empowerment and the way forward. PalArch's Journal of Archaeology of Egypt/ Egyptology, 17(6), 3957-3975.

Månsson, N., \& Landström, H. (2006). Business angels in a changing economy: The case of Sweden. Venture Capital, 8(4), 281-301. https://doi.org/10.1080/13691060600836275

Poczter, S., \& Shapsis, M. (2018). Gender disparity in angel financing. Small Bus. Econ., 51(1), 31-55.

Pronschinske, G. M., Grozaa, M., \& Miguel, B. L. (2020). Women backing women: The role of crowdfunding in empowering female consumer-investors and entrepreneurs. Journal of Business Research, 117(C), 432-442.

Stuart, P., Whittam, G., \& Wyper, J. (2007). Towards a model of the business angel investment process. Venture Capital, 9(2), 107-125. https://doi.org/10.1080/13691060601185425

Sullivan, D. M., \& Meek, W. (2012). Gender and entrepreneurship: a review and process model. Journal of Managerial Psychology, 27(5), 428-458. https://doi.org/10.1108/02683941211235373

Tenca, F., Croce, A., \& Ughetto, E. (2018). Business angels research in entrepreneurial finance: a literature review and a research agenda. Journal of Economic Surveys, 32(5), 1384-1413. https://doi.org/10.1111/joes.12224

Yadav, V., \& Unni, J. (2016). Women entrepreneurship: research review and future directions. Journal of Global Entrepreneurship Research, 6(12), 1-18.

Yaokuang, L., Shuoyuan, S., Dan, L., Huidao, T., \& Juan, W. (2014). An exploratory study of business angels in China: a research note. Venture Capital, 16(1), 69-83. https://doi.org/10.1080/13691066.2013.833370

Yasuhisa, T. (1999). Business angels in Japan. Venture Capital, 1(3) $259-273$. https://doi.org/10.1080/136910699295893

\section{Copyrights}

Copyright for this article is retained by the author(s), with first publication rights granted to the journal.

This is an open-access article distributed under the terms and conditions of the Creative Commons Attribution license (http://creativecommons.org/licenses/by/4.0/). 